\title{
The last Princes of Stuck and the West
}

\author{
BY
}

J. KRA.JCAR, S.J.

The duchy of Słuck

Trifon Korobejnikov, a well-travelled Muscovite who visited Constantinople and Jerusalem in 1582-84, was once again sent to the monasteries of the East nine years later. ${ }^{1}$ He left Moscow on 19 January 1593 and journeyed this time across the Grand Principality of Lithuania, touching several of its towns. To no other town of Lithuania did he pay more attention than to Słuck: ${ }^{2}$ the city was built of wood, in size, smaller than Kolomna. There was in it the fortified castle area with 200 houses, but the suburbs (posad) were larger than Rostov. Two rivers, Veś and Słuč, met about one verst from the city. The last river could swell to the size of the river Moscow. The multitude of the population and the liveliness of the city market amazed the Muscovite greatly. ${ }^{3}$ Guards and riflemen were stationed at the gates of the fortified area, and no foreigner could enter without being interrogated.

Słuck was the capital of the duchy of Słuck, bearing the same name as what was considered the most powerful autonomous duchy in Lithuania.

Complimentary words about the duchy were voiced by Alessandro Guagnini (1538-1614) of Verona, who for 18 years was commander of the royal forces in Viciebsk, and thus had both the ability and possibility to familiarise himself with the political and social conditions of Poland-Lithuania. He concluded that the duchy of Słuck was the most powerful among the autonomous territories of the Grand Principality, estimating its dimensions at 30 Polish miles in

1. For Trifon Korobejnikov and his travels see Russkij biografičeskij slovar', IX, SPB, 1903, pp. 267-9.

2. His Report has been edited twice: Ctenija Obšč. Ist. i Drev. ross., I, pp. 1-18: Vtoroje choždenije Trifona Korobejnikova, p. 7; Pravoslavnyj Palestinskij Sbornik, IX, vyp. 3, SPB, 1889, pp. Ixxv-125: Choždenije Trifona Korobejnikova 1593-1594 gg., for Słuck see pp. 74-5.

3. See Z. Ju. Kopysskij, Ekonomičeskoje razvitije gorodov Belorussii (XVIXVII vv.), Minsls, 1966, p. 31; the author estimates the population of the three parts of Słuck at 10,000 inhabitants in 1655 .

A. Grickevič, Sluck, istoriko-ekonomičeskij očerk, 2-e izd., Minsk, 1970, p. 10, calculates the number of houses at 1100 , consequently the number of inhabitants at 7000 , at the end of the 16th century. Those are likely data. His assertion that the number of houses is indicated in Korobejnikov's Report, is, however, gratuitous. 
length and 30 in breadth. And its prince 'by his personal wealth may be placed on equal footing with German and Italian princes'. ${ }^{4}$ Only then does he discuss the power of the Chadkieviči and Radziviłs, though the last happened to be by the middle of the century the richest Byelorussian family. They took a vivid interest in politics and in holding remunerative public offices; since 1547 they were distinguished by the high Imperial title of 'Princes of the Empire', while the Słuckis, boasting of their royal ancestry, stood aloof.

An even more flattering bit of information was left to us by Peter Skarga, while writing to his fellow Jesuit Antonio Possevino. He estimated the size of the duchy - not without exaggeration at 40 miles in length and 40 in breadth; and supposed its annual income to be 60,000 Lithuanian kopa, i.e. 150,000 florins." At the same time he pointed to commerce as the source of this wealth. He mentioned expressly the waterway Słuč - Pripiać - Dniepr and the caravans journeying to Kiev and as far as Turkey. Commerce in the opposite direction, via the Nioman to Königsberg and Western Europe was even more important. ${ }^{6}$

The economic strength of the duchy may be calculated from the number of the land levy servicemen. At the assembly at Maładziečna in 1567 Nicholas Radzivił accoutred 539 horsemen and 386 footmen; next to Radzivił was George of Słuck with 478 horsemen and 300 footmen. ${ }^{7}$

The duchy of Słuck became a vassal of Lithuania in 1326, and in 1395 was given to the Lithuanian prince Vladimir Alherdovič, after he had been expelled from the much greater territory of Kiev. The suppression of large principalities such as Viciebsk, Smolensk, Połack and Kiev was correlative with the formation of smaller duchies such as Kleck, Kobryn and above all Słuck. The founder of the princes of Słuck was considered Alexander (Alelko) Vladimirovič, prince of Kiev ( $\dagger 1454)$, second son of Vladimir Alherdovič. After his father

4. Alexander Guagnini, Rerum Polonicarum tomi tres, Francofurti, 1584, I, p. 97; idem, Sarmatiae Europeae descriptio, Spirae, 1581, fol. 62.

5. Letier of June 1579, Monumenta Poloniae Vaticana (subsequently referred to as MPV), IV, ed. Lud. Boratyński, Cracoviae, 1915, p. 203. For the duchy's boundaries in the 16th century see Jan Jakubowski, Mapa Wielkiego Księstwa Litewskiego $w$ połowie XVI wieku, Atlas Historyczny Polski, 1, Kraków, 1928. For a contemporary map see Magni Ducatus Lithuaniae... descripto, Amsterodami, 1613, published by Wilhelm Blaeu (Radzivil's map). In this map the length of the duchy from the upper Nioman (slightly beyond Pjasečno) in the north to the basin of Pripiac in the south is about 23 common miles as the crow flies.

6. There is a rich literature on the economic and commercial history of Słuck. We offer some selected entries: M. Doŭnar-Zapolski, 'Socialna-ekonomična struktura Litoŭska-Białaruskaje dziaržavy u XVI-XVIII stalećciach', Histaryčna-archieałahičny zbornik, I, Minsk, 1927, for Słuck see pp. 44-6 and passim; A. P. Grickevič, 'Povinnosti žitelej častnovladel'českogo goroda Belorussii v XVI-XVIII vv.', Materialy konferencii molodych učenych AN BSSR, Minsk, 1962, pp. 116-22; idem, "Torgovyje svjazi Slucka s gorodami Pol'ši i Pribaltiki v XVI-XVIII vekach $i$ ich rol' $v$ inozemnoj torgovle goroda', Acta Baltico-Slavica, VI, Białystok, 1969, pp. 51-73 (with relevant li'terature quoted).

7. I. I. Lappo, Velikoje knjažestvo Litovskoje vo vtoroj polovine XVI stoletija, Jur'jev, 1911, pp. 60 ff., 578 ff., 580. 
Simeon Alelkavič became prince of Kiev, while the second son Michael Alelkavič (†1481) became prince of Słuck and Kapyl. ${ }^{8}$

\section{George Jur'jevič and Catherine Tęczynska}

The ruler of the duchy and father of the last princes of Słuck was George Jur'jevič (1542-1578).

In religion, culture and politics his guiding principle was the starina, fidelity to the Orthodox tradition of old, and it was his unswerving will that his sons should follow in his footsteps. On the other hand he realized that a new cultural wave in connection with the Catholic revival was penetrating into the Greek-Slavic lands. And he was aware that the native Slavic tradition had nothing analogous with which to oppose it. He attempted to establish at his court a centre of Slavic culture. He welcomed in Słuck men of letters; M. Stryjkowski, who praised his generosity, was one of them. ${ }^{9}$ Probably for the same reason he received with open arms Artemius, the fugitive monk from Muscovy. He did not see in him primarily 'a zealous fighter for Orthodoxy';0 after all Artemius was suspect of heresy. George recognised in Artemius a man who could contribute to setting up a school in Słuck. But Artemius could not realise the plans of the prince, for he knew only his native Slavic tongue and without Latin such a centre was unthinkable.

In religious matters Artemius was as tolerant as his host; there is nothing in his writings hostile to the Catholic Church. ${ }^{11}$ When Symon Budny, pastor in nearby Kleck, published in 1562 at Niaśviž a reformed Catechism, Artemius reacted not by attacking but by imploring him to desist from his errors. ${ }^{12}$ Later on, Catherine Tęczynska informed Anthony Possevino about a monk from Muscovy who had found hospitality in Słuck and who 'cherished a best opinion of the Catholic Church and acknowledged her excellence'. ${ }^{13}$

The old prince harboured great respect for revived Western Christianity, disliked some insipid observances imposed on the Ruthenian Church, and admitted that the recently published book censuring some Ruthenian religious practices was in the right, nor could any Orthodox answer it satisfactorily. ${ }^{\mathbf{1 4}}$

The repeatedly voiced opinion that Słuck could boast as early as the eighties of the 16 th century of a school and printing press, cannot

8. M. K. Ljubavskij, Oblastnoje delenije $i$ mestnoje upravlenije LitovskoRusskogo gosudarstva ko vremeni izdanija pervogo Litovskogo Statuta, Ctenija, 1892, 3, 1-62;4,63-296; 1893, 3, 297-764;4,765-884, for the duchy of Słuck pp. 23-25, 133. For the Alelkaviči see A. Boniecki, Poczet rodów $w$ Wielkiem Księstwie Litewskiem $w$ XV i XVI wieku, Warszawa, 1887, pp. 316-21; J. Wolff, Kniazowie Litewsko-Russcy, Warszawa, 1895, pp. 327-36.

9. M. Stryjkowski, Kronika polska, litewska, żmodzka $i$ wszytskiej Rusi, t. I-II, Warszawa, 1846, p. ix.

10. S. G. Vilinskij, Poslanija starca Artemija (XVI veka), Odessa, 1906, p. 111.

11. Ibid., pp. 120-1.

12. Ibid., p. 119.

13. MPV, IV, p. 203.

14. Ibid., the book concerned is P. Skarga, O Jedności Kościoła Bożego poc jednym Pasterzem, w Wilnie, 1577. 
be sustained. Anthony Possevino was responsible for this piece of information, but he got it from hearsay. At the end of the Firs' Commentary on Muscovy he mentions that a school and a typography had been established by the princes of Ostrog and Słuck in their respective towns. ${ }^{15}$ Ostrog had both; as to Słuck, it was only a plan or wishful thinking. ${ }^{16}$ (We are speaking of a real school that could compete with Jesuit Colleges. Nobody contests the possibility of receiving a rudimentary education in the monastery of the Most Holy Trinity or in some other monastery, where children could learn to read the Casoslov or other Slavic books). That the project of establishing a real school had already been ventilated in the life time of the old prince, can be concluded from the fact that the young princes picked up the plan immediately after their return from abroad. Ir. 1582 they proposed that the Jesuits establish a College in Słuck. ${ }^{17}$ The order declined the offer. The Society had not enough members Besides, they preferred royal towns, in order not to get involved in feuds between nobles. There was also the danger of fire: with the exception of one or two churches Słuck was built of wood, - and this discouraged them from considering the project. The first school comparable to Jesuit Colleges was erected in 1624 by the Calvinist Christopher Radzivił, commander-in-chief of Lithuania. ${ }^{18}$ There are no sources proving the existence of a printing press in our period, and no printed piece edited there is known. The first printing press was installed in Słuck as late as $1670 .^{19}$

Though deeply attached to Greek traditions, George Jur'jevič did not mind entertaining friendly relations with the activators of the Catholic restoration movement or being in correspondence with the Holy See. Gregory XIII invited the prince to join the Catholic Church, 'in which his ancestors, the kings of Poland, attained their glory'. ${ }^{20}$ The papal courtesy letter was written November 1, 1578, nine days before his death, but it arrived in Lithuania several weeks later.

Fr. Skarga was chosen to bring the Roman message to Słuck. He knew that the old prince was no longer alive. He had already offered his condolences to the widow Catherine Tęczynska. ${ }^{21}$ This was expected, if only because the duchess was the daughter of Stanislas Tęczynski, Castellan of Cracow (†1561) whom Skarga knew.

Though the duchess' father was a Pole and a Latin, she was also familiar with Ruthenian traditions. Her mother Anna Boguševa was of Ruthenian stock, and her grandmother Fedora Andreevna descend-

15. 'Habent autem ii duces, qualis est Ostrogiae et Slucensis, Typographias et Scholas, quibus schisma fovetur.' Moscovia, Coloniae, 1687, p. 11.

16. The existence of a school and a press in Sluck in 1581 is also upheld by A. Grickevič, Słuck, p. 10.

17. The letter of Adam Brock to General Aquaviva, 26 Sept. 1582, Archivum Romanum Societatis Jesu (cited hereafter as ARSJ), Germ. 160, fol. 185.

18. K. Charlampovič, Zapadnorusskija pravoslavnyja školy XVI $i$ načala XVII veka, Kazan', 1898, p. 159.

19. Drukarze dawnej Polski od XV do XVIII wieku, z. 5, Wielkie Księstwo Litewskie, Wrocław-Kraków, 1959, pp. 231-4.

20. The papal letter of 1 Nov. 1578, MPV, IV p. 65. 
ed from the Sanguško family.22 In Słuck these traditions were steadily gathering strength. She was neither of Ruthenian, nor of 'Polish' belief and she agreed to abide by her indecision, an attitude possible at that time, before the Catholic forces gathered their impetus. One practice of the Greek rite - the communion under both species - was particularly dear to her..$^{23}$ Both the Nuncio and the Jesuits made efforts to dissuade her from this practice, for a long time without avail. Being courteously requested by Skarga to join the Catholic Church, she expressed the judgment that salvation might be assured in both the Roman and Greek Churches alike, provided that one live up to the faith inherited from his parents. Being invited to educate her sons in the Catholic religion, she replied that for the time being this topic could not be discussed, because in case of their infidelity to Eastern beliefs, her sons would be deprived of their father's blessing and even of their patrimony. ${ }^{24}$

We are unable to trace in detail the spiritual itinerary of the duchess. Among the circumstances that resulted in her definite return to the faith of her father, should be reckoned the religious sluggishness of the Ruthenian Church, the vitality of Counter-reformation Catholicism, memories of her youth, a certain drawing off from the Ruthenian environment after the death of her husband, the persuasive religious zeal of her second cousin Andrew Tęczynski, Palatin of Cracow after 1582 and finally the influence of some Jesuit priests. Her decision probably matured at the end of 1579 , in any case before the date when her sons went abroad.

When the news spread that Catherine Tęczynska was entering a new marriage with Nicholas Christopher Radzivił, Castellan of Troki, and a Calvinist, the representatives of the Catholic restoration movement at first were annoyed. But their second thought was different. Nuncio Bolognetti was probably expressing the opinion of many when he wrote to Secretary of State Cardinal Como that the Castellan of Troki though a heretic, 'was a man endowed with every sort of virtue'25 and Bolognetti cherished hopes that Radzivił might follow his wife's example and convert to Catholicism himself; thus it might well be that this land of Lithuania, where the good seed seemed to be springing up, would yield a rich harvest and open its gates to the Catholic Church.

Such expectations did not materialize, but the duchess remained faithful to her religion, and kept in touch with the Nuncio and the Jesuits. It was not the religious issue that troubled the peace of her soul, but rather the contentions and legal actions of her sons against

21. J. Sygański T. J., Listy Pietra Skargi T. J. $z$ lat 1566-1610, Kraków, 1912, pp. $107,109$.

22. A. Boniecki, Herbarz Polski, I, Warszawa, 1901, p. 361.

23. K. Chodynicki, Kościol prawoslawny a Rzeczpospolita Polska, Warszawa, 1934, pp. 227-8; O. Halecki, From Florence to Brest, Rome, pp. 205-8.

24. J. Sygański, op. cit., p. 107; MPV, IV, pp. 201-2; for the will of George Jur'jevič see Snitko, 'Opisanije dokumen'tov sostavljajuščich 1-yj tom Sluckago Trojčanskago archiva', Minskaja starina, IV, Minsk, 1913, p. 3.

25. Nuncio Bolognetti to Cardinal Como, Secretary of State, 28 June 1583, MPV, VI, Kraków, 1938, p. 376. 
her and her new husband concerning temporal goods. Bolognetti relates a particular scene: at a banquet Catherine received the sentence of the court of Lublin, ordering her to pay Alexander 50,000 florins. She burst into tears, not over the loss of money, but because - she declared, the injury had been inflicted by her own son. ${ }^{\mathbf{2 6}}$

The Słuckis and the Jesuits

The duchess of Słuck and two of her sons, Alexander and John Simeon, embraced the Catholic faith. Want of sources eludes a detailed inquiry into the motives of this conversion. In their quest for faith, Alexander and John Simeon were assisted by two Jesuit priests. The first, Stanislas Włoszek, planted the seed that was to mature when they went abroad. Włoszek's role as adviser and friend of the family was taken over by Simeon Wysocki, some time after 1581. The influence these two Jesuits exerted on the Słuckis is mentioned by the official historian of the Society Francesco Sacchini. ${ }^{27}$ He had at hand some documents from Poland - Lithuania. It is also evidenced to by contemporary correspondence..$^{28}$

Stanislas Włoszek was born in Juchnoviči in Paleśsie - Jesuit catalogues call him Subsylvanus - in about $1555 .{ }^{29}$ He received his first education at home, for humanities he went to Braniewo and Vilna. He joined the Society of Jesus on 21 Sept. $1573 ; ;^{30}$ then he completed the full course of philosophy and theology at Vilna. Great hopes were laid on him from the very beginning. He was called 'consolation of superiors' and proclaimed 'a man fit to hold any office in the Society'. He showed talent for preaching, teaching and a great zeal in the apostolate. Dealing with people, he was handicapped by a certain slowness, and when he became a superior, his insistence on observing rules easily turned into harshness; religious poverty was diverted to a state of penury and want. This was the case in the first years of his career. He took his time in making decisions, and because of his much appreciated prudentia he was chosen a companion to Fr. Sawicki for dealing in Cracow with Pseudo-Demetrius. ${ }^{31}$

In 1585 the residence of Połack was transformed into a College and Fr. Włoszek was named its first Rector; he remained, amidst many

26. Bolognetti to Como, 10 Febr. 1584, MPV, XII, Kraków, 1950, p. 69.

27. 'Iuvit Collegii huius initia et Catharina Tecinska Slucensis Dux, eiusdem modo laudati Palatini Cracoviensis soror, quae una cum filiis duobus a schismate Rutheno, opera maxime P. Stanislai Wlosek ac Simonis Visocii, hoc ipso tempore abducta, non destitit deinceps magnis Ordinem nostrum beneficiis demereri.' Franc. Sacchini, Historiae Societatis Jesu pars quarta, tomus prior, Romae, 1669 , p. 8.

28. Campano to Aquaviva, 29 Dec. 1582, ARSJ, Germ. 160, fol. 284.

29. For Włoszek's family see K. Niesiecki, Herbarz Polski, IX, Lipsko, 1842, p. 377.

30. ARSJ, Pol. 7, fol. 172.

31. Scriptores rerum Polonicarum, X (diary of the Jesuit house in Cracow), Kraków, 1886, p. 57. 
difficulties, in this office for over five years. ${ }^{32}$ He was made professus quattuor votorum on the first of January, 1592. ${ }^{33}$ For five years he was Superior of the domus professa in Warsaw, his name occurs frequently on the pages of Wielewiecki's diary of St. Barbara's in Cracow, where he was also Superior for a short time. ${ }^{34}$ He died in Warsaw on 20 May 1621 at the age of $65 .^{35}$

The sources do not disclose when Fr. Włoszek met the Słuckis for the first time. It is not excluded that he met Catherine of Tęczyn already in his native Paleśsie; the duchess possessed some estates there. Probably Catherine herself asked the Provincial to send a Jesuit as an adviser in religious matters, and the Provincial sent Fr. Włoszek. The latter had no facility for making friends and even less in keeping them. This talent was granted in large measure to his fellow-Jesuit Simeon Wysocki, who soon replaced Stanislas Włoszek as the spiritual adviser to the Słuckis.

Simeon Wysocki was born in Kurjany (Polish Kurzany), in a village owned by his family near Berežany, today in the USSR, in the western part of the Ternopil'ska oblast'. 36

He studied in L'vov and Cracow 'for many years'; in 1565 we find his name among the siudents of the University of Cracow. ${ }^{37}$ Peter Skarga suggested to Wysocki, at that time a deacon, that he join the Society of Jesus. ${ }^{38}$ Both were received in the order by the General Francis Borgia, and both entered the Roman novitiate on February 2,1569 . Wysocki was made professus 3 votorum in March, $1571{ }^{39}$ His ordination to the priesthood took place in Rome and among the participants at his first mass was Cardinal Hosius.

After returning to his native country, he devoted his energies to preaching, placing emphasis on the explaining the main tenets of the faith rather than on a mere exhortation. He dedicated his forces to correcting social injustices and alleviating the sufferings of his fellow-men. He founded hospitals for incurables in Poznań, Vilna and Lublin; he was generally known as 'father of the poor'. Despite his intensive missionary work he succeeded in translating into Polish more than 28 ascetical books, 'with which he filled the whole king-

32. ARSJ, Germ. 164, fol. 80v; Pol. 6, fol. 4v.

33 . Some catalogues put 1591 , but the right year can be easily gathered from the letter the Provincial Maselli wrote to the General on 8 Jan. 1592: Germ. 170, fol. 10; also Pol. 7, I, fol. 318v.

34. Scr. rer. Pol., XL, 268.

35. ARSJ, Lith. 6, fol. 26r; Hist. Soc. 43, fol. 213r.

36. For Wysocki's family see K. Niesiecki, Herbarz Polski, IX, pp. 460-1; C. Sommervogel, Bibliothèque de la Compagnie de Jésus, t. VIII, ParisBruxelles, 1898, p. 1311 designates the birth plare of Wysocki as Kurzany in the district of Vilna; an error, because the Jesuit catalogues state: Kurzany in Russia and Wysocki is named Roxolanus ex dioecesi Leopoliensi.

37. ARSJ, Pol. 6, fol. 5; in the Register of students at Kraków University for the year 1565 is an entry that refers to Wysocki: Album studiosorum universitatis Cracoviensis, ed. Adam Chmiel, III, Cracoviae, 1896, p. 57.

38. Scr. rer. Pol., XIV, Kraków, 1889, p. 75.

39. ARSJ, Pol. 6, fol. 112v and other catalogues. 
dom, especially the nunneries to their great spiritual benefit', as a contemporary biographical sketch comments. ${ }^{40}$

At the end of 1577, he received orders to join the Swedish mission - missio Suetica - which was under the direction of Fr. Stanislas Warszawiecki. He stayed in Sweden for several years, ${ }^{41}$ and only on 22 July 1581 do we find him in Poland again.

In 1592 he was sent to Rome to take on the duties of a penitenziere ${ }^{42}$ in St. Peter's but after a few months he succeeded in returning to his native land. He went to Lublin, which he loved more than any other place. But his Provincial was of a different opinion, and sent him to Vilna. ${ }^{4: 3}$

His talents were not complemented by prudence; his sermons sometimes contained impertinent phrases which offended prominent persons. ${ }^{4 !}$ His strong point was not dogmatic theology, but morals (his contemporaries called them casus), but he would not dwell on subtle distinctions, so to speak, 'splitting hairs'. His brethren were sometimes embarrassed by oddities in his apostolic method, though all his superiors agreed that this lack of discretion was never accompanied by malice.

Rhetoric and striving for brilliance were alien to him. He was persuaded that unilateral humanism was incompatible with true Christian piety. In his funeral oration on John Simeon Alelkavič, he declared that panegyrics and rhetorical efforts do not become a Christian preacher; even scholarship itself, if not aiming at the edification and benefit of souls, should be dismissed. ${ }^{45}$

Wysocki's name occurs frequently in the diary of St. Barbara's house in Cracow and he ended his days in this house on 12 June $1622 . .^{46}$

He probabiy got acquainted with the Teczynski family while a student in Cracow. Later Lublin was his preferred residence, and he could meet the Słuckis when they were visiting their possessions in Lublin or Kraśnik. He was of Ruthenian stock, a man of faith and deep piety, and full of zeal for the house of the Lord. Reading the descriptions of him left by his contemporaries, there emerges a man of God that in the Russian cultural contex $t$ would be called jurodivyj. But the very qualities that embarrassed his fellow Jesuits and annoyed his superiors endeared him to the people and to the nobility, the Słuckis included.

40. This Eulogium is ceposited in ARSJ, Pol. 68, I, fol. 81. For his writings see C. Somervogel, op. cit., VIII, pp. 1311-20.

41. For this period of Wysocki's life see O. Garstein, Rome and the Counterreformation in Scandinavia, I, 1961, passim.

42. A college of 13 Jesuits, confessors of St. Peter's basilica, instituted by Pius V.

43. Maselli to Aquaviva, 7 June 1593, ARSJ, Germ. 171, fol. 179: 'Trat enim mutatio ei gravis, cum sit nimium addictus Lublino, seu potius amicis quibusdam nobilibus, qui eum magni faciunt.'

44. The city council of Vilna sent o complaint to the Provincial, Campano to the General, 6 April 1591, ARSJ, Germ. 169, fol. 86v.

45. T. Grabowski, Piotr Skarga na tle katolickiej literatury religijnej $w$ Polsce wieku XVIm, Kraków, 1913, pp. 250-1.

46. ARSJ, Hist, Soc. 42, fol. 114r; Pol. 43, fol. 170r. 
On 26 May 1582 Catherine Tęczynska informed General Aquaviva of her conversation with Fr. Wysocki: the tertianship was to be transferred from Branievo to Jarosław and she was willing to finance the transfer. Because rumours were circulating to the effect that Fr. Wysocki might be sent to Sweden once more, the duchess opposed the removal of her spiritual counsellor and stubbornly added that she would discuss the transfer only with Wysocki.47

The duchess was disposed to give the Jesuits more than they were willing to accept. Kraśnik, a town not far from Lublin, was one of her possessions. ${ }^{48}$ She resolved to erect a college in her town of Kraśnik; the Lateran canons regular were to be expelled and the property of the Collegiate would serve as an endowment for the College. The Provincial refused the offer, in spite of her insistence. Not only did he not want to make enemies among other religious families, but he was also aware that simall and insufficiently protected towns were exposed to many perils and the College could be expected to suffer from these. ${ }^{49}$ Furthermore, the Provincial was probably annoyed by the dictatorial manner of the duchess and feared that she would meddle in the internal affairs of the school. He felt relieved on hearing that Catherine's attention became focussed on her new marriage, and that the estates she wanted to reserve for the new College were being claimed by her sons.

Despite minor discords the duchess continued to be friendly and generous to the Jesuits. She presented the College of Lublin with 6,000 florins, adding a beautiful orchard she possessed on the outskirts of the same city. Each of her three sons promised the institution 2,000 florins. ${ }^{50}$

Her sons were in contact with the Jesuits: Alexander with those of Cracow, John Simeon with those of Lublin, in particular with Wysocki. The apostolate that was new in Poland-Lithuania and won the Jesuits much sympathy was the catechetical work among the destitute and ignorant rural population. Only basic Christian tenets, without regard to communion, were taught. Such an apostolic expedition was undertaken by Jesuits in the rural areas of John Simeon's possessions; this was at the invitation of the prince himself. ${ }^{51}$ At that period the Jesuits were welcomed by the country population. Only much later did the Orthodox monks stir up some strife against them, though they themselves were utterly indifferent to instructing their faithful.

47. 'Quodsi omnino Pater Simeon mittendus in Suetiam esset, res ista de novitiatus translatione non posset tam facile concludi, nec vellem per aliquem alium nisi per P. Simeonem eandem finiri.' ARSJ, Epp. Exter. 28, fol. 199 .

48. For Kraśnik see Stownik Geograficzny Królestwa Polskiego, IV, Warszawa, 1883 , pp. $630-3$.

49. Campano to the General, 21 Sept. 1582, ARSJ, Germ. 160, fol. 176v; also: MPV, V, Cracoviae 1923-1933, p. 491.

50. For the history of the Lublin College see St. Zalęski, Jezuici w Polsce, IV, cz. 1, Kraków, 1905, pp. 327 ff; ARSJ, Pol.-Lith. 75, (Fundationes), fol. 55-8.

51. St. Rositowski, Lituanicarum Societatis Jesu Historiarum libri decem, Parisiis-Bruxellis, 1877, p. 113. 
The Princes of Słuck and the Union of Lublin

The long-standing custom whereby a member of the Alelkaviči family kept a seat in the Senate-rada of the Grand Duchy of Lithuania immediately after the Bishop of Vilna, was challenged by the Union of Lublin 1569. In the united Senate prevailed the system, already in use in the Crown Diet, whereby there were no hereditary senators but only those who held higher office were admitted. ${ }^{52}$

George of Słuck defied the Union of Lublin on this ground. He and his sons were struggling for their privileges against confrontation and opposition by the West, i.e. by the Polish Senate structure. In support of their claims was the principle of starina alone. They could not stop the process of democratisation that was questioning the feudal prerogatives of old, and they could not reverse the development in their favour.

What consequences the Lublin agreement entailed for Byelorussian princes could be anticipated. A few months before the Union of Lublin, Eustace Valovič, Deputy Chancellor of the Grand Duchy wrote to Roman Sanguško and alluded to what was in the mind of all; he insisted on maintaining the solidarity of all Lithuanian nobles, adding: 'Let us keep in mind the venerable antiquity'. The case of the Princes of Słuck was expressly mentioned..$^{5: 3}$

George of Słuck did not take part in the negotiations of Lublin: he was either affected by or simulated sickness; he apologized for his absence. His name was frequently heard, if for no other reason than on account of his controversy with Nicholas Radzivił, Palatin of Vilna. ${ }^{54}$ After the Union had been accomplished he had no choice but to put his name on the document, and he was allowed to take his oath before the royal commissaries separately. ${ }^{55}$

His wife, Catherine Tęczynska was given notice to present herself at Lublin on 24 April 1569 to take the oath to the King and to the crown because she held possessions in Padlasie, a province newly annexed to the Polish crown. ${ }^{56}$

At the Sejm of Warsaw in 1572 (12 March - 28 May) Constantine Astrožski pleaded the cause of the Alelkaviči. Sigismund II August was or pretended to be favourable to the request, but the decision was deferred to the next assembly. ${ }^{57}$ The king died on 7 July 1572.

The Convocation Diet in Warsaw 1573 (5 January - 28 January) received a letter of George of Słuck, dated 30 December 1572, in which he asked for approval of what had been promised by the late

52. St. Kutrzeba, 'Skład sejmu Polskiego, 1493-1793', Przegląd Historiczny, II, 1905 , pp. 43-76; for the princes of Słuck, p. 68.

53. Letter of Vałovič to Sanguško on 29 Nov. 1568, Archiwum Ksiazat Sanguszków $w$ Slawucie, VII, Lwów, 1910, pp. 305-7.

54. M. O. Kojalovič, Dnevnik Ljublinskago sejma 1569 goda, $\mathrm{SPb}, 1869$, pp. $120-1$.

55. S. Kutrzeba, W. Semkowicz, Akta Unji Polski z Litwa 1385-1791, Kraków, 1932 , pp. $382-3$.

56. Ibid., p. 231.

57. Ibid., p. 392. 
King. In the very last session the Sejm promised to comply with his request, that he be granted a seat in the Senate. ${ }^{58}$

A few weeks later, the Election Diet took place in the outskirts of Warsaw (5 April - 20 May). Surrounded by his armed men George of Słuck joined it. He felt he was in the right, and on two occasions, 22 April and 2 May, sought in vain to occupy the senatorial seat by force. He was repulsed by some Byelorussian magnates, in particular by the men of John Chadkievič, Lieutenant of Samogitia and Nicholas Radzivił, Palatin of Vilna, who were hostile to him for personal reasons and were ready to meet force by force. ${ }^{59}$

The young Słuckis were no less keen than their father to regain the seat in the Senate. They hoped to achieve their goal with the help of district assemblies which they tried to gain for their cause. ${ }^{60}$ Petitions from the diatenes did not impress His Majesty, because some envoys refused to sign them on the grounds that the office of senators ought not to be hereditary in a kingdom where the royal dignity was elective. ${ }^{61}$

Equally unsuccessful was their attempt at the Warsaw Assembly on 21 February 1585. While the argument was being ventilated the Castellan of Halyč probably voicing the opinion of many, declared that much time had been already wasted in discussing the senatorial seat of the Słuckis. The princes should be given offices, which would entitle them to cast votes and to sit at the King's side; 'there are no born senators in this country'. ${ }^{62}$

As time lapsed, their chances decreased and their hopes seemed to be entirely extinguished. The princes, father and sons, wasted a lot of money and energy in trying to regain what they considered their hereditary privilege. They felt that wrong had been done to them. They were unaware that the starina, the political and social structure of old, was yielding to democratisation, and that this process had been accelerated in the last decades by the Renaissance ethos penetrating from the West, in particular from Italy. The prerogatives of birth alone are of no weight, if not accompanied by the 'virtù' by personal achievement, enterprise and vitality.

The Słuckis lost their political battle with the Renaissance West. Their abilities were mediocre, and they were tempted to compensate for their lack of talent by adopting overbearing behaviour. Their display of pomp was not persuasive, they did not learn the art of the possible. Bolognetti overheard some remarks made over John Simeon by people from the king's entourage: he - Simeon - did not measure up to people's expectations; in vain had he stayed in Italy. ${ }^{63}$

58. Kronika Marcina Bielskiego, Warszawa, 1764, pp. 602-3.

59. Scr. rer. Pol., XXII, Kraków, 1917, pp. 83-4, 93.

60. For the district sejmik at Vaŭkavysk see the letter of Bolognetti to Como, 26 Jan. 1582, $M P V$, V, pp. 199-200.

61. Ibid., p. 220.

62. Scr. rer. Pol., XVIII, Kraków, 1901, p. 307; also Adolf Pawiński, Akta Metryki Koronnej z czasów Stefana Batorego 1576-1586, Warszawa, 1882 (Żródla dziejowie, XI), p. 268, 314.

63. 'Non respondit multorum expectationi, frustra vixisse in Italia videtur.' Bolognetti to Como, 6 March 1582, MPV, v, p. 264. 
George III Jur'jevič (†1586) and his daughter Sophia (†1612)

A few months before his death George Jur'jevič Alelkavič enjoined his wife Catherine to send their sons abroad for a period of two or three years, 'as is proper to members of high born families.' ${ }^{64}$ The old prince died on 9 November, 1578 and a few months after his demise concrete projects were made probably with the advice of Andrew Teczynski, Palatin of Belz, second cousin of the widow. The eldest, George, was to journey to France, England and Spain; John Simeon was to be sent to Italy, and the youngest, Alexander, to Ingolstadt in Germany. ${ }^{65}$ From the material at my disposal I cannot determine whether George's trip to the West did materialize. His brothers, however, did go. Their journey period was reduced to about a year, and was accomplished between spring of 1580 and spring or summer of 1581 . The primary purpose of their journey was not educational; they did not seem to be fond of studies. They were meant to acquire some experience and to become men of fine breeding, as well as making themselves known.

On 6 July 1582 the testament of the old prince was executed and the heirs were allotted their respective towns, villages and estates. Słuck was divided into three parts: George received the Old city, John Simeon the New city and Alexander Ostrov. The respective document enumerates in detail other possessions. ${ }^{66}$

George remained Orthodox but entertained friendly relations with the Nuncio and the Jesuits.

At the wedding of Griselda and Jan Zamojski all three brothers were present. Before leaving for Słuck George called on Bolognetti, attributing his visit to the respect every Christian should have for the Supreme pastor of Christianity. ${ }^{67}$ Their conversation probably concerned the plan George disclosed in his letter to Gregory XIII less than a month later. On 6 July, 1583 he asked the Pope for Greek priests who would staff the main churches in his territory ${ }^{68}$ for those priests 'who follow the most pure and Catholic doctrine of Basil, John Chrysostom and Gregory of Nazianzus' ${ }^{69}$

In further conversation with George Bolognetti proposed that he adopt the Catholic faith. The answer was that he could not betray venerable antiquity and his ancestors. The Nuncio read his visitor's mind well and tried to explain what true antiquity meant. Thereupon George promised to consult those who represented his authority in religious matters. Bolognetti insisted that these problems were to be

64. Snitko, 'Opisanije dokumentov .. .', Minskaja starina, IV, Minsk, 1913, p. 3.

65. Caligari to Como, 28 March 1580, MPV, IV, p. 407.

66. Snitko, op. cit., p. 4.

67. Bolognetti to Como, 10 June 1583, MPV, VI, p. 346.

68. The letter of George of Słuck to Gregory XIII, MPV, VI, p. 383.

69. The feasi of the three Ecumenical Doctors is celebrated on 30 Jan. Veneration of them was considered a sure test of Orthodoxy. Placing them together denoiced sometimes an anti-Latin bias, though George was unaware of it. Latin Chrisians were accused of neglecting the veneration of these three Ecumenical Doctors. See A. Popov, Istoriko-literaturnyj obzor drevne-russkich polemičeskich sočinenij protiv Latinjan (XI-XV v.), Moskva, 1875, p. 50 . 
cleared up in consulting with persons who walk the right way of the Greek fathers, in conformity with the Council of Florence.

Gregory's answer to George's request was prompt and promising. ${ }^{70}$ But the Pope pledged something he could not fulfil. In fact, there were no such priests in Rome at that time. The Secretary of State Cardinal Como informed Polognetti about the real situation, and the Nuncio had to convey the unpleasant news to George of Słuck. ${ }^{71}$

The prince was 25 when he married Barbara Kiščanka, daughter of Nicholas Kiška, Palatin of Padlasie, but he died a year later on 6 May 1586. The funeral took place at the end of July with the participation of numerous Byelorussian nobles. He was buried in the main church of Our Lady (soborna) in the Old city. ${ }^{72}$

The only daughter of George of Słuck was Sophia, born on 1 May 1585. She was the last and probably the most unhappy offspring of the Alellraviči. Very early on she was deprived of both her father and mother, since Barbara Kiščanka soon entered a new marriage with Andrew Sapieha, starosta of Homiel. The guardians of the child, the Chadkieviči, later kept her in their house in Vilna. A violent feud broke out between them and the Radziviłs, not because of her beauty, of which we know nothing, but because of her riches, since she had inherited her father's possessions and also some of both her uncles' ${ }^{73}$

The agreement between the two families stipulated that the 15-year-old princess would be given to Januš Radzivił of Birži and Dubinki, cupbearer of Lithuania. Since they were related in the fourth degree, the prince asked Clement VIII for dispensation. ${ }^{74}$ From the text of this petition some have concluded that Sophia was considered Orthodox. The wording of the document favours the other opinion. This is also implied by the very fact that an application was made to Pome at all. A Calvinist husband and Orthodox wife would not care a bit for papal dispensations. There should also be taken into account the wishes of Sophia's guardians, George Chadlievič, starosta of Samogitia, and Jerome Chadkievič, Castellan of Vilna after 1595. The unhappy girl had hardly any chance to advance her own wishes and preferences in religicus matters or otherwise: not before her marriage and even less thereafter. Nuncio Rangoni considered her a Catholic. On 3 January 1604 he wrote to the Secretary of State of rumours to the effect that the son of the Palatin of Vilna

70. Letter of Gregory XIII to George of Słuck of 3 Sept. 1583, MPV, VI, p. 515.

71. The letter of Bolognetti to George of Słuck 7 Oct. 1583, MPV, VI, pp. 592-3.

72. J. Wolff, op. cit., p. 335 referrs to Afanasij Kal'nofojskij, Teratourgema, Kiev, 1638 , p. 30 (the book was no' accessible to me) and says that George Jur'jevič had been buried in the Pečersk monastery. There is probably a confusion of George Jur'jevič and his father by both auchors. George was buried in the 'soborna cerkov' in Słuck: see M. Baliński, T. Lipiński, Starożytna Polska, III. Warszawa, 1846; A. Snitko, 'Iz Sluckoj stariny', Minskaja starina, II, Minsk, 1911, pp. 159-75; on p. 60 is men'tioned the Gospel book that was believed to have been copied by George Jur'jevič in 1582. The text adds that the prince was buried in the church of Our Lady (soborna) in Słuck.

73. Wolff, op cit., p. 335.

74. Dated 20 July 1600 , Sobronije drevnich gramot $i$ aktov gorodov Minskoj gubernii, Minsk, 1848, pp. 66-7. 
had died. If this were the case, it would entail positive consequences, 'above all for the duchess of Słuck, a Catholic, that would be liberated from pains of soul and body'. ${ }^{75}$

Sophia's marriage was untimely; so was her death on 9 March $1612^{76}$ Before her death she transferred her enormous fortune to her husband. The inscription that 'the most sorrowful husband' had engraved on the sarcophagus of his 'most desired wife' does not include any details other than but a long list of her glorious ancestors. ${ }^{77}$

The coffin of the last duchess of Słuck was on display in the 19th century in the church of the most Holy Trinity in Słuck. ${ }^{78}$ There was something tragic about this last offspring of the Alelkaviči dynasty and the people surrounded her with an aura of holiness. In times of plague and other natural disasters they used to carry in procession about the city the body of Sophia and the body of a little boy - presumably a victim of ritual murder in Zabłudaŭ. ${ }^{79}$

\section{Alexander Jur'jevič (†1591)}

It was agreed that Alexander would learn the manners of a gentleman at the University of Ingolstadt. Since the Jesuits had taken it over, it attracted many students from Poland-Lithuania. In 1580, when Alexander was admitted to the University, the number of enrolled students from the Commonwealth was 34 , the highest number in the history of the University. A good number of them were aulici et famuli, but even these were obliged to register in accordance with the University regulations. ${ }^{80}$ Alexander of Słuck was accompanied by 15 persons, more than any other noble. Ordinarily the suite of a noble student, even of those of powerful families, did not exceed 5 or 7 persons. Alexander and his retinue matriculated on 28 May $1580 .^{81}$

Most of the information about Alexander's sojourn in Ingolstadt was furnished by contemporary historians of the University, ${ }^{82}$ who had the chance of speaking with Alexander and with Jan Dzierżek 'prefect of Alexander's court'. Dzierżek was the King's Secretary

75. A. Welykyj, Litterae nuntiorum apostolicorum historiam Ucrainae illustrantes, II, Romae, 1959, p. 225.

76. E. Kotłubaj, Galerya Nieświeżska portretów Radziwiłłowskich, Vilno, 1857, p. 160, adds that she was buried in the Church of Our Saviour in Euck.

77. Simeon Starovolscius, Monumenta Sarmatarum beatae Aeternitati adscriptorum, Cracoviae, 1655, p. 765.

78. A. Snitko, 'Iz Sluckoj stariny', art cit., p. 157, describing the church of the most Holy Trinity, makes reference to the sarcophagus, with its inscription, that held Sophia's body. The inscription gives 1617 as the date of her death, but this is certainly false.

79. B. J. K., Wspomnienia o Slucku, Gniezno, 1905, p. 18.

80. C. Prantl, Geschichte der Ludwig-Maximilians-Universität in Ingolstadt, Landshut, München, I, München, 1872, p. 283.

81. P. Czaplewski, Polacy na studyach w Ingolsztacie, Poznań, 1914, p. 25.

82. Valentinus Rotmarus, Joannes Engerdus, Almae Ingolstadiensis Academiae tomus primus, Ingolstadii, 1581, pp. 49-53; Joannes Nep. Mederer, Annales Ingolstadiensis Academiae, II, Ingolstadii, 1782, pp. 58-65. 
and Batory employed him frequently as an envoy to Germany, the Netherlands and Spain..$^{83}$

Alexander did not hide his sympathy for the Catholic Church and probably on his own initiative the question of joining the Catholic Church was broached. This met the willing ears of many and somebody brought it to the attention of Wilhelm the Pious, Duke of Bavaria (1579-97). The Duke went to Ingolstadt to settle some outstanding affairs, to receive the oath of the citizens, to visit the University and last but not least to direct or confirm the descendant of Jahailo's dynasty in the path of righteousness. For the explanation of Catholic tenets the Duke recommended to the prince Fr. Gregory of Valencia, ${ }^{84}$ a great scholar and luminary of the University. The Spaniard accepted the call to arms with satisfaction, and thanks to his wise instruction, Alexander declared his readiness to enter the fold of the Church ${ }^{85}$ To perform the official reconciliation ceremony, the Duke of Bavaria invited Martin of Schaumberg, Bishop of Eichstädt (1560-90), a man of vast culture, master of several languages, zealous in Church reform, and esteemed by Catholics and Protestants alike. ${ }^{86}$ Wilhelm the Pious visited Ingolstadt in August 1580; consequently the reconciliation did take place, probably in the autumn of the same year, though these details did not come down to us.

Alexander made every effort to extend the circle of his acquaintances. The names may have been suggested to him by Dzierżek. He went to Strassbourg looking for John Sturm, former Rector of Strassbourg University. But the great scholar had already been living for four years on his country estate Nordheim. ${ }^{87}$ Alexander did not venture to the rural area, but sent Sturm his good wishes through the famous jurist Joannes Lobartus. The wishes were probably made more substantial by the inclusion of a gift of money. Sturm was not ungrateful. He acknowledged Alexander's attention, wrote a grateful letter that was used as the preface to Sturm's short treatise on education. The preface bears the date 27 May $1581{ }^{88}$

Visiting Basel, a city of the Swiss confederation, Alexander called on Theodor Zwinger (1533-88), a scholar who in the true humanist

83. For a brief biographical notice see Polski Stownik Biograficzny, VI, Kraków, 1948, p. 160.

84. For a summary account of his life and his work see: A. Vacant, E. Mangenot, Dictionnaire de Théologie Catholique, XV, Paris, 1950, col. 2465-97. Gregory of Valencia dedicated to Alexander a short work: Disputatio Theologica de vera et falsa differentia veteris et novae Legis... Ingolstadii, 1580, see Sommervogel, op. cit., VIII, 390; see also: S. Estreicher, Bibliografia Polska Karola Estreichera, XXXII, Kraków, 1938, p. 162.

85. Ignatius Agricola, Historia Provinciae Societatis Jesu Germaniae Superioris, I, Augustae Vindelicorum, 1727, p. 230.

86. E. Reiter, Martin von Schaumberg, Fürstbischof von Eichstädt (1560-1590) und die Trienter Reform, Münster, 1965.

87. John Sturm lived in seclusion on his estate (Sturmianum praedium) at Northeim near Marlenheim from 1576 until 1589. See Historisch-topographisches Wörterbuch des Elsa $\beta$, bearbeitet v. Joseph M. B. Clauss, Zabern, 1895, p. 782.

88. Epistola ad Illustrissimum Principem ac Dominum, Dominum Alexandrum Ducem Slucensem et Copulensem... Argentorati, 1581; see S. Estreicher, op. cit., XXIX, Kraków, 1933, p. 369. 
tradition was expert in different fields: medicine, ethics and Greek. ${ }^{89}$ Zwinger dedicated his edition of Aristotle's Nichomachean Ethics to Alexander. The dedicatory preface was signed on 13 March 1582 and though it fills 6 pages, it provides no historical information, being only a glorification of the Alelkaviči family that supposedly has vindicated 'first place among senators and grandees of the state'. ${ }^{\mathbf{9 0}}$

On his return from Ingolstadt, Alexander settled in Słuck in expectation of his portion of the patrimony. Having received his share on 6 July 1582, he displayed more dynamism than his older brothers. He tried hard to win that place in society which he thought worthy of his ancestors. This was to be achieved by an advantageous match and by a radical improvement of his finances.

His clesign was definite: to take in marriage somebody from among the kindred of the King. He wished to marry Griselda, niece of Stephen Batory, daughter of Batory's brother Christoph. But the King had to repay the good services rendered by Chancellor Zamojski. The wedding took place on 12 June 1583, in the presence of many guests; the princes of Słuck refrained from showing any sign of disappointment. On the contrary, they contributed to the festive atmosphere by arranging some triumphant scenes to honour both the King and the Chancellor. ${ }^{91}$

Alexander misjudged reality and did not consider his hopes defeated. I $t$ was said that he would marry the sister of Griselda; in reality there was no such sister. Other rumours reported that he would certainly marry one of the sisters of Griselda's mother, viz. of Elisabeth Boczkay Kismarjal. In reporting these rumours Bolognetti was rather sceptical about their veracity, surmising that these were being spread by friends of Zamojski for reasons of their own. ${ }^{22}$

Already in 1583 there was talk that Alexander was to enter the King's service. This is the last that Bolognetti had to say about Alexander. ${ }^{93}$ Anyway, he felt more at home in Cracow than elsewhere. ${ }^{94} \mathrm{He}$ was well known to the higher clergy of that city. On 28

89. A short notice in A. Burckhardt, Geschichte der medizinischen Fakultät zu Basel 1460-1900, Basel, 1917, pp. 89-95.

90. Theodorus Zwinger, Aristoteles Ethicorum Nicomachiorum libri decem, Basileae, 1582; full title in K. Estreicher, Bíbl. Polska, XII, Kraków, 1891, p. 212.

91. Adamus Titus, comes de Kościelec Działyński, Collectanea vitam resque gestas Joannis Zamoyscii... illustrantia, Posnaniae, 1861; it includes: [R. Heidenstein], De Nuptiis Illustrissimi Joannis de Zamoscio... ac Griseldis Bathoreae ... epistola, Cracoviae 1583, p. 171, 184; see also Script. rer. Pol., VII, Kraków, 1881, p. 47.

92. Bolognetti to Como, at the beginning of $1583, M P V$, VI, pp. 9, 32, 153; George II Kismarjal (†1571) and Christine Sulyok had eight children, four of whom were girls: Sara, Helen, Christine, Judith; see Iván Nagy Magyarország Családai, II, Pest, 1858, p. 130.

93. Bolognetti 'to Como, 8 July 1583, MPV, VI, p. 392.

94. Stanisław J. Kolakowski, Cathemerinon Księstwa Stuckiego... v Wilnie, 1593, deplores the extinction of the Alelkaviči and alluding at this period of Alexander's life implies that the prince was staying most of the time in Poland.

p. [10]: Zdobil oyczyzne swoie w tey Polskiey Koronie

Słynal iak niegdy Parys on $w$ Troianskiey stronie. 
August 1590 his relative John Tęczynski asked him to put a word in with the Bishop of Cracow for a certain Pawlejczel. Pawlejczek was a member of the community of the Lateran Canons at Corpus Christi in Kazimierz (Cracow) and former servant of Tęczynski. The latter attempted to procure for his protégé the dignity of Prior of that community..$^{95}$

Want of money and poor health began to trouble him very soon. ${ }^{96}$ Death, though untimely, did not take him by surprise. On 8 June 1591 he bequeathed the rossessions he had inherited from his rnother to Barbara Kiščanka, some others to his brother John Simeon. A few days later he expired in Cracow on 26 June $1591 .^{97}$ The very fact that the day of his passing is noted in the diary of St. Barbara's house combines with other circumstances to testify that he lived and died a Catholic.

\section{John Simeon Jur'jevič (†1593)}

John Simeon was the last of the princes of Słuck in the male line. He spent his years of 'apprenticeship' in Italy where he learnt the Italian way of life in Bologna, a city dear to many from PolandLithuania. ${ }^{98}$

His arrival in Italy was preceded by a letter addressed to the General of the Society of Jesus, Ev. Mercurian, and by a letter the duchess of Słuck wrote to Gregory XIII, in which she expressed her concern about the faith of her son and recommended him to the paternal care of His Holiness. The Pope immediately informed Cardinal Gabriel Paleotto, Bishop of Bologna, a man steeped in the ideals of the Council of Trent. He found in one of the priests of the Jesuit College the right person to instruct the prince, 'a youth of about 20 years'. This was facilitated by the fact that John Simeon harboured sympathy for the Catholic Church before his coming to Italy. ${ }^{99}$

There was not the slightest reference to reconciliation according to the principles of the Council of Florence. As a matter of fact, strange things happened.

The Jesuit had not finished giving instructions, when the prince expressed his desire to be received into the Roman communion,

95. A. Prochaska, Archiwum domu Sapiehów, Lwów, 1892, p. 62.

96. Ibid., p. 24, 31-2.

97. Scr. rer. Pol., VII, p. 143.

98. M. Bersohn, Studenci polscy w Universytecie Bolońskiem $w$ XVI i XVII $w$, I-II, Kraków, 1890, 1894; the book does not make any reference to John Simeon's sojourn in Jologna. The prince probably did not apply for admission to the University.

99. All we know about the sojourn of Johi Simeon in Bologna derives from two Jesuit sources: Litterae annuae of 1581, in ARSJ, Ven. 105, I, fol. 143 and a short account written abou't 1603, in which an unknown Jesuit put down all he had learned from a fellow-Jesuit who had instructed the prince in the Catholic faith. Ibid., fol. 69-71. See also MPV, IV, p. 407. 
together with his suite of 13 persons. ${ }^{100}$ We do not know, however, whether some preferred to refrain. The project to make a baroque display of the reconciliation ceremony was abandoned and the ceremony took place in the chapel of the Jesuit College. Before long the prince spent several days in seclusion, probably in the recently founded monastery of Camaldolese. On this retreat he was attended by two servants only.

A great solemnity took place on the feast of St. Petronius, Patron of Bologna. This day, 4 October 1580, is the only exact date of John Simeon's sojourn in Italy. The Cardinal administered the sacrament of confirmation to the prince and his companions without the least sign of scruples; in fact, the prince and his suite (probably all them of Greek rite) had been confirmed at their baptism. Then at the solemn mass they received Holy Communion from the hands of the Cardinal. The General of the Society was also notified in time about this 'conversion of a Polish Prince' and he expressed his sincere congratulations to Fr. Francis Palmio in Bologna. ${ }^{101}$

John Simeon also visited Rome. ${ }^{102}$ A short time before his arrival, the erection of a new hospice for pilgrims from Poland-Lithuania had been approved. Together with other nobles who were staying in Rome at that time the prince made a substantial contribution. Among the nobles was Nicholas Mielecki, Palatin of Podolia, whose daughter John Simeon was to marry six years later.

We may assume that Alexander and John Simeon were already in Słuck in 1581, and consequently their peregrination lasted more or less one year. ${ }^{103}$

Alexander and John Simeon professed loyalty to the Catholic Church until their death. At the same time they fulfilled their duties as patrons of numerous Orthodox churches and monasteries. There is no sign of any attempt to impose a religious confession on any of their subjects according to the principle cuius regio, eius religio. As a matter of fact Słuck remained a stronghold of Orthodoxy and hostile to the Union with Rome.

In 1586 John Simeon married Sophia Mielecka, elder daughter of Nicholas Mielecki, Palatin of Podolia, a zealous Catholic. John Simeon

100. In Ven. 105, I, fol. 70 are named persons who accompanied John Simeon to Italy. The spelling of their names is distorted and the names themselves, all high-sounding, raise suspicion. They are: Andrew Peter Jazłowiecki, Nicholas Samborski, John Boresoniski, Gaspar Oborski, Jerome S'riž, Joseph Polubienski, Andrew Prusnicki, Andrew Krasnorski, Alexander Polubienski, Gregory Laski, Peter Tryzna, Frederic(!) Masal'ski, Retapsus Malbues(?).

101. ARSJ, Ven. 2, (Epp. Gener.), fol. 37v, a congratulatory letter from the General to Fr. Palmio, da'ied Oct. 1580.

102. H. Barycz, Polacy na studiach $w$ Rzymie $w$ epoce odrodzenia (1440-1600), Kraków, 1938, p. 186.

103. See K. Kantak, 'Najważniejsze rękopisy franciszkańskie bibliotek wileńskich', Ateneum Wileńskie, V, 1928, pp. 175-84; on page 183 among those who in the years 1580-81 enrolled for the Confraternity of St. Anna in Vilna are also Alexander and John Simeon. 
died on 9 March $1592,{ }^{104}$ victim to the plague that was raging all over the country at that time; he was buried in the Jesuit church in Lublin. ${ }^{105}$ The faithful friend of the Słuckis Fr. Simeon Wysocki preached the burial sermon on 29 April 1593. ${ }^{106}$

Mielecka was deeply shaken by the passing of her beloved, though rather passive husband. Her first intention was to begin living a half-monastic secluded life, reserving most of her assets for endowing Jesuit Colleges. ${ }^{107}$ The Jesuits were rather embarassed by the generosity of the young widow, for several reasons. One of them was that prospective husbands could start fomenting hostility against them. They counselled her to postpone any decision in the matter. They felt relieved when Mielecka entered a new marriage with Charles Chadkievič, Commander-in-chief of the Grand Duchy on 23 July 1593. She was a 'typical old-Polish matron', comments Wanda Dobrowolska in a short biographical sketch. ${ }^{108}$

John Simeon was the last male of the Alelkaviči family. As soon as the King came to know about his death, he sent his secretary Bojanowski to Słuck. Some asserted that the Alelkaviči held their possessions as fiefs and as such they should revert to the crown. It became, however, very soon clear that their possessions were allodial. ${ }^{109}$

104. 'The Memoires of Theodore Jeułašeŭski, Assessor of Navahrudak (15461604)', ed. Alexander Nadson, Journal of Byelorussian Studies, I, 4, London, 1968 , p. 319.

105. Jesuit sources frequently mention the plague; several Jesuit Colleges, Lublin included, had been closed.

106. For the full title of the Sermon published in Vilna in 1593, see Sommervogel, op. cit., VIII, p. 1312.

107. She wanied to found a College in L'vov because she possessed some estates in the area. She determined in detail how much this and other Jesui'c Colleges should share in her generosity. See the letter of the Provincial Boxa to Aquaviva of 15 April 1594, ARSJ, Germ. 172, foll. 143.

108. Polski Stownik Biograficzny, III, Kraków, 1937, pp. 371-2.

109. J. Bielski, Dalszy ciag Kroniky polskiej... (1587-1598), Warszawa, 1851, p. 154; A. Guagnini, Rerum Polonicarum ..., p. 293.

\section{Authors of articles in Vol. III, No. 3}

J. ZAPRUDNIK, Assistant Professor of History, Queen's College, New York University.

P. J. MAYO, Lecturer, Dept of Slavonic Languages, University of Sheffield.

J. KRAJCAR, S. J., Professor of History, Pontifical Oriental Institute, Rome. 